\title{
From Francis Coralie Mullin to Swaraj Abhiyan: Adding Multidimensionality to the Conditional Social Right to Food
}

\author{
Saurabh Bhattacharjee*
}

\section{Abstract}

Global hunger is widely seen as one of the foremost threats to humanity. The Constitutionality of the Right to Food has been a long-standing debate within the Indian Subcontinent as there is no explicit mention of the said right. Through various judicial pronouncements over a relatively long period of time, the right to food has been construed to be constitutionally ingrained. This paper explores the history of the right to food as a fundamental right in India, as per the Constitution. It analyses landmark cases on the right to food and examines the fundamental right to food, in terms of state obligations. Is the impact of the entrenchment of the right to food as a fundamental right, limited only to its symbolic meaning? Or has such right substantively shaped the contours of governmental policies too? What are the remedial interventions that the judiciary has made in view of the constitutional right to food? These are questions that the paper will explore. In this process, the paper will parse various judicial orders on the right to food and identify whether there are justiciable entitlements that presumptively constitute the core of the right. Further, the

* The West Bengal National University of Juridical Sciences, Kolkata, India; bhat.saur@nujs.edu 
paper shall also highlight the multidimensionality of the right to food and illustrate that starting with Francis Mullin in the 1980s, to Laxmi Mandal and Swaraj Abhiyan in this decade. The courts have, through the above mentioned judgments, underscored the interrelatedness between the rights to food, health, shelter and right to work.

Keywords: Article 21 of the Constitution of India, Conditional Social Sight Approach, Content of the Right, People's Union for Civil Liberties, Right to Food, Francis Coralie, Swaraj Abhiyan

\section{Introduction}

We, the Heads of State and Government, or our representatives, gathered at the World Food Summit at the invitation of the Food and Agriculture Organization of the United Nations, reaffirm the right of everyone to have access to safe and nutritious food, consistent with the right to adequate food and the fundamental right of everyone to be free from hunger. ${ }^{1}$

Global hunger is widely seen as one of the foremost threats to humanity. In fact, the World Food Programme asserts that "hunger and malnutrition are in fact the number one risk to health worldwide- greater than AIDS, malaria and tuberculosis combined." 2 This is reflected in the estimates of the United Nations Food and Agriculture Organization which suggest that about 795 million people of the 7.3 billion people in the world, were suffering from chronic undernourishment in 2014-2016. Worryingly for India, one of the largest number of undernourished people hails from this country. India has, therefore, been placed 97th out of 118 countries, on the Global Hunger Index, by the International Food Policy Research Institute in Washington. ${ }^{3}$ Ironically, such

${ }^{1}$ Rome Declaration on World Food Security and World Food Summit Plan of Action 1996, http:/ / www.fao.org/docrep/ 003/ w3613e/ w3613e00.htm.

2World Food Programme, Hunger, available at https:/ / www.wfp.org/hunger (last visited on Oct. 29, 2016).

3 Priyanka Vora, India Has Programmes to Alleviate Hunger But Not the Will

to Enforce Them, Scroll.in, Oct. 15, 2016, 
widespread starvation and hunger exists in a context of adequate food production. Global per capita availability of food has risen from about $2220 \mathrm{kcal} /$ person/day in the early 1960s to 2790 $\mathrm{kcal} /$ person/day in the last decade. ${ }^{4}$ The problem of starvation, therefore, arises primarily from the problems of unequal distribution and access to food. ${ }^{5}$

Amartya Sen had famously argued that the Great Bengal famine of 1943 was not a direct product of overall shortage of production of food crops but a consequence of the powerful inflationary impact of the economic distortions caused by policy changes after the Second World War. ${ }^{6}$ It has been claimed that the response to hunger must focus as much on questions of social systems that ensure distributional access to food, as on total production. ${ }^{7}$ It is pertinent to note, in this context, that one can generally procure food by either producing the food himself or by buying it in the market. When they are not in a position to do either, especially due to lack of purchasing power, it becomes imperative to create legal entitlements to ensure access to food. A constitutional statutory right to food performs this valuable function towards guaranteeing access to food to all persons through justiciable entitlements.

India has recognised the centrality of the right to food within its constitutional framework, right from the inception of the Republic. Article 47 of the Constitution asserts that the "[s]tate shall regard the raising of the level of nutrition and the standard of living of its people and the improvement of public health as among its primary duties". 8 Even though this provision is non-justiciable and aspirational, it is normatively significant for the acknowledgment

http:/ / scroll.in/pulse/819067/india-has-programmes-to-alleviatehunger-but-not-the-will-to-enforce-them.

4 Supra note 3.

5Jacquline Mowbray, The Right to Food and the International Economic System: An Assessment of the Rights-Based Approach to the Problem of World Hunger, 20 LEIDEN JOURNAL OF INTERNATIONAL LAW 545 (2007).

6AMARTYA SEN, POVERTY AND FAMINES: AN ESSAY ON ENTITLEMENT AND DEPRIVATION, 75-77 (Oxford University Press, 1983).

${ }^{7}$ Id.

8 INDIA CONST., art. 47. 
of nutritional security as a primary mandate of the state. Further, the non-binding Directive Principles have been considered by the Indian judiciary as a vital component aiding in the interpretation of the scope of fundamental rights. ${ }^{9}$ Thus, the right to food has slowly permeated into the jurisprudence of fundamental rights through the interpretive expansion of right to life in the decade after the Emergency. ${ }^{10}$ Through several cases in the last three decades, the right to food has been grounded within the right to life, as a fundamental right to life, enshrined in Article 21 of the Constitution. ${ }^{11}$ The sustained intervention of the Apex Court in the People's Union for Civil Liberties (PUCL) case has firmly entrenched the right to food as a fundamental entitlement, so much so it has also acted as a catalyst for enactment of the National Food Security Act, 2013.12

\section{Expanding Article 21: Right to Food as an Unenumerated Constituent of Right to Life}

As mentioned earlier, the right to food was enshrined in the Constitution as a non-justiciable Directive Principle of State Policy in Article 47. However, the gradual expansion of the ambit of the fundamental right to life that took place in the 1980s' embraced the right to food within its scope too. ${ }^{13}$ The first major case where the linkage between right to food and the right to life was underscored by the judiciary was Francis Coralie Mullin $v$ The Administrator. ${ }^{14}$ Ironically, this case was not directly related to hunger or starvation,

\footnotetext{
${ }^{9}$ Olga Tellis v. Bombay Municipal Corporation, AIR 1986 SC 180.

10 Jean Dreze, Democracy and Right to Food, 39 (17) ECONOMIC AND POLITICAL WEEKLY 1723 (April 24, 2004).
}

11 Id.

12 Lauren Birchfield and Jessica Corsi, Between Starvation and Globalization: Realising the Right to Food in India, 31 MICH. J. INT'L L.J 691 (2009).

13 Supra note 10; See also Paul O'Connell, Vindicating Socio-Economic Rights: International Standards and Comparative Experience (2012) and K.C. Prakash, A Critical Analysis of Right to Life and Judicial Interventions in South Asian Countries, 3 KATHMANDU SCH. L. REV. 198 (2013).

${ }^{14}$ AIR 1981 SC 746. 
but arose from a habeas corpus petition challenging the conditions of detention of a foreign national arrested under an anti-smuggling statute and his rights of access to lawyers and members of his family. While dealing with the petition, the Supreme Court relied on an American precedent to rule that "the right to life enshrined in Article 21 cannot be restricted to mere animal existence." 15 The Court went on to observe that the "right to life includes the right to live with human dignity and all that goes along with it, namely, the bare necessaries of life such as adequate nutrition, clothing and shelter."16 This pronouncement not only paved the way for incremental expansion of right to life, wherein several socioeconomic rights were read into the right, ${ }^{17}$ but also, explicitly grounded right to food as a direct constituent of the right to life.

However, since the case did not directly deal with starvation and hunger, it had a limited impact on setting out the normative content of the right to food, especially regarding governmental policies. This was not the case with Kishen Pattnayak $v$ State of Orissa ${ }^{18}$ which pertained to a Public Interest Litigation, (PIL) alleging starvation deaths of inhabitants in districts of Kalahandi and Koraput, due to negligence of the District Administration and the Government. The Supreme Court admitted the petition and directed the District Judge of Kalahandi to enquire as to whether the State Government had implemented the social welfare measures in the district and assess the adequacy of the same. Based on the Report of the District Judge and provisions of Orissa Relief Code, the Court directed the State Government to form the Natural Calamities Committee for the District, as per the Orissa Relief Code and "nominate the names of at least five persons belonging to recognized voluntary organisations." 19 The Court also clarified that the "function of the Committee will not be confined only to the

${ }^{15} \mathrm{Id}$. at 769.

${ }^{16} \mathrm{Id}$. at 771 .

17J.S. Verma, Recent Judicial Trends in Enforcement of Freedoms, 27 COMMW.

L. BULL. 571 (2001).

18AIR 1989 SC 677.

${ }^{19} I d$. at 261. 
cases of starvation deaths, but it shall be responsible for looking after the welfare of the people of the district." 20

This judgment did not make any direct mention of the right to food as a fundamental right. Yet, the case is a major milestone in the development of right to food, for the very fact that a petition related to starvation was admitted under Article 32 of the Constitution. Since the power under Article 32 can be invoked by the Supreme Court only in a case involving violation of a fundamental right, the admission of the petition and subsequent grant of relief together constitute a tacit indication that a fundamental right had been impinged through starvation deaths. Therefore, despite its silence, the judgment in Kishen Pattnayak is seen as a step towards the recognition of a fundamental right to food, or at the very least, a right against starvation in an implicit manner.

\section{Direct Affirmation of the Right to Food}

If Kishen Pattnayak had not explicitly spoken of a fundamental right to food, the Supreme Court was far more direct in situating the right to food in Part III of the Constitution in People's Union for Civil Liberties $v$. Union of India and Others. ${ }^{21}$ The case originated from a PIL filed, in July 2001, in the backdrop of a prolonged drought and agrarian crisis, against the state of Rajasthan, due to its failure to provide employment and food relief as mandated by the Rajasthan Famine Code of 1962.22 In a series of interim orders, the Supreme Court recognized the right to food as derived from Articles 21 and 47 of the Constitution and "explicitly established a constitutional human right to food in India". ${ }^{23}$ In more concrete terms, the Court held that several existing governmental schemes connected with nutrition, constituted legal entitlements under the fundamental right to food. Through the instrument of continuing mandamus

${ }^{20} I d$.

21Writ Petition (Civil) No. 196 of 2001.

22 Supra note 12.

23Dipika Jain and Brian Tonic, Implementation of the Public Distribution System: An Empirical Analysis of the Right to Food in an Urban Slum, $12 \mathrm{~J}$. FOOD. L. \&POL'Y 53 (2016). 
and several interim orders, the Supreme Court steered the direction of these schemes and laid down the contours of the mode of their implementation. ${ }^{24}$ These orders have cumulatively entrenched the right to food as a core fundamental right in the Indian constitutional milieu. But the question that arises as a result is whether the recognition of the right to food has a concrete impact on state policies. Similarly, another critical issue that requires further inquiry is whether the Court's intervention in the PUCL case reveals a coherent conception of the duties that comprise the right to food.

Every legal right enjoins a corresponding duty and indeed, the crux of a legal right lies in the fact that it vests a co-related obligation on another person or a set of persons. A rhetorical articulation of a legal or a constitutional right does not carry any substantive weight, without clarity on corresponding duties. ${ }^{25}$ Therefore, the normative recognition of right to food within the Indian constitutional framework can be a mere cosmetic exercise without rigorous analysis of the duties that the right carries. However, since a major portion of the judicial dicta in the PUCL case is in the form of interim orders that revolve around the nuts and bolts of governmental schemes on nutrition, they lack a direct articulation of the core enforceable content of the right to food. ${ }^{26}$

In view of this lacuna, this part of the paper shall map out the different axis of intervention of the judiciary, on cases pertaining to the right to food with the aim of throwing some light on the content of the right. Judicial intervention on right to food in India, as shaped by the PUCL case and other associated decisions, have broadly involved: a) Identification of schemes that constitute legal entitlements, b) Modification of existing schemes, c) Fixation of

\footnotetext{
${ }^{24}$ Supra note 12.

${ }^{25}$ See generally for an assessment of rights and duties, Henry Shue, Basic Rights: Subsistence, Affluence and US Foreign Policy, Princeton (1980).

${ }^{26}$ Yamini Jaishankar and Jean Dreze, Supreme Court Orders on the Right to Food: A Tool for Action (2005), http:// www.righttofoodindia.org/data/scordersprimer.doc.
} 
accountability of officers and d) Establishment of an institutional framework for monitoring enforcements.

The initial intervention of the Supreme Court in the PUCL case revolved around transformation of administratively established food security schemes into enforceable legal entitlements. The first major interim order of the Supreme Court in this case, passed on 28 th November 2001, focused on eight food-related schemes: (1) the Public Distribution System (PDS); (2) Antyodaya Anna Yojana (AAY); (3) the National Programme of Nutritional Support to Primary Education, also known as "Mid-Day Meal Scheme" (MDMS); (4) the Integrated Child Development Services (ICDS); (5) Annapurna; (6) the National Old Age Pension Scheme (NOAPS); (7) the National Maternity Benefit Scheme (NMBS); and (8) the National Family Benefit Scheme (NFBS). Through subsequent interim orders, the Sampoorna Gramin Rozgar Yojana (SGRY) was also turned into a legal entitlement. Most of the later interim orders were concerned with modalities of implementing these schemes. ${ }^{27}$ The conversion of the benefits assured by these schemes into constitutional entitlements was practically significant in so far as persons who were denied these benefits could claim their due as a matter of right and approach a court of law for appropriate recourse.

In addition to identifying schemes that formed constitutional entitlements, the Court also shaped the trajectory of these schemes. In fact, the benefits available under these schemes have also been altered through judicial dicta. These modifications are illustrated by the changes brought about by the Supreme Court to the MDMS. The Court called upon all the State Governments to introduce cooked mid-day meals in primary schools and instructed them to replace monthly ' dry rations' of grain with daily, cooked mid-day meals. Further, it also mandated that the states continue the MDMS in schools in drought affected areas during the summer vacations too. The other major notable modification was the direction on universalisation of ICDS, a scheme aimed at providing young children with a package comprising of supplementary nutrition,

27Supra note 12. 
health care and pre-school education. It also aimed at supporting adolescent girls, pregnant women and lactating mothers. The Court mandated that ICDS services should never be restricted just to BPL families alone, but to all children of a specific age-group. ${ }^{28}$

Similarly, the annual allocation of both cash and food grains for the Sampoorna Gramin Rozgar Yojana('food for work') employment programme during the months of May, June, and July was doubled by the Court. The Court also directed the state governments to focus the SGRY programme towards agricultural wage earners, non-agricultural unskilled wage earners, marginal farmers and, in particular, SC and ST persons whose wage income constitutes a reasonable proportion of their household income. In the same order, the Court also prohibited the use of contractors for the SGRY. The Judiciary's endeavour to modify the content of the nutritional schemes is also illustrated by the alterations proposed to AAY scheme. The Court ruled that the aged, infirm, disabled, destitute men and women, pregnant and lactating women, destitute women, widows, (2) widows and other single women with no regular support; (3) households with disabled adults, (4) denotified primitive tribes, should be brought within the ambit of priority households and should be entitled to Antyodaya Card as a matter of right. Most critically, the Court also restrained the Government from unilaterally modifying the scheme. The Court stated that "no scheme covered by the orders made by this Court... shall be discontinued or restricted in any way without the prior approval of this Court." 29

\section{The Need for Fixation of Accountability}

A novel step taken by the Court in the PUCL case, was to precisely pinpoint the responsibility of implementation of the scheme and its

${ }^{28}$ Yamini Jaishankar and Jean Dreze, Supreme Court Orders on the Right to Food: A Tool for Action (2005), http:// www.righttofoodindia.org/data/scordersprimer.doc.

${ }^{29}$ Yamini Jaishankar and Jean Dreze, Supreme Court Orders on the Right to Food: A Tool for Action (2005), http:// www.righttofoodindia.org/data/scordersprimer.doc. 
directions on specific officers. The Court recognized that affixation of individual responsibility on particular officers and institutions would induce more robust implementation and identified the officers to be held responsible. In the case of State Governments, the Chief Secretary was made answerable to the Court on behalf of the government. As far as orders addressed to specific departments or ministries were concerned, it was held that the Secretaries of those departments or ministries would be responsible for the implementation of orders relevant to them. Moving on to districtlevel compliance, the Court indicated that the CEO/ Collector would be responsible. ${ }^{30}$

The Supreme Court not only turned the existing nutrition-related schemes into constitutional legal entitlements but also tried to setup an institutional mechanism for monitoring the implementation of these schemes. On the one hand, the Court strengthened the role of existing Panchayati Raj institutions. The Gram Sabhas were held to be entitled to conduct social audit into all Food/Employment schemes and to report all instances to misuse of funds to the respective implementing authorities. On the other hand, the Court setup parallel bodies too. The Court appointed two Commissioners through two separate orders in 2002 and 2003. They were given the task of looking into grievances regarding food entitlement schemes and monitoring and reporting the extent of implementation. They were also empowered to take assistance from other reliable persons and organizations. 31 In pursuance of this mandate, the Commissioners also appointed several state-level advisors to "function as a bridge between the Commissioners, state governments, and civil society." 32 These officers have been able to provide contemporary information about compliance from the field level to the Supreme Court, thus shaping the directions of subsequent orders. They have also facilitated better administrative response to the judicial orders through dialogical engagement with government functionaries. According to Birchfield and Corsi:

30 Yamini Jaishankar and Jean Dreze, Supreme Court Orders on the Right to Food: A Tool for Action (2005), http:// www.righttofoodindia.org/data/scordersprimer.doc.

31 Supra note 26.

32 Supra note 12. 


\begin{abstract}
The Commission seeks open lines of communication to encourage state implementation and to propose modification of food and work policies. The work of the Commission is largely focused on building relationships with state officials and using those successfully forged partnerships to resolve grievances and foster political will for implementation of court orders. 33
\end{abstract}

In addition, the Court provided significant space to civil society organizations which were behind the original petition. This combination of Court-appointed Commissioners, Advisors and civil society campaigns, engendered a robust framework for monitoring and strengthening the implementation of the schemes. This has resulted in well-crafted directions from the judiciaries, which have been supplemented by vigorous supervision on implementation.

\title{
VI. Multidimensionality and Conditional Approach: Exploring the Content of Right to Food
}

In the preceding section, the different axis of judicial intervention on the right to food have been mapped out. A PIL that was filed against the Union of India and a few states, currently applies to all state governments. This case has also triggered many similar petitions seeking judicial monitoring of food security schemes at the High Court level .34 The sustained intervention on the part of the Court on a myriad of issues, including hunger, child nutrition and development, and unemployment, has led to an overhaul of the public distribution system in India and has expanded access to food security for many deprived sections of the Indian citizenry. Given that the case originated in a politico-economic context of gradual roll back of public distribution service that was attempted in the late 1990s, Supreme Court's involvement safeguarded public food security schemes from further assault in the name of liberalization and privatization. ${ }^{35}$ But what do these orders say

${ }^{33} \mathrm{Id}$. at 728.

${ }^{34}$ Supra note 23.

${ }^{35}$ Supra note 12. 
about the content of the right to food? In this section, it is argued that an analysis of judicial dicta in the PUCL case and other related cases reveal the following about the Indian judiciary's conception of the right to food: a) multidimensionality of right to food and b) conditional content of the right.

The constitutional right to food has been interpreted in a holistic manner, where the linkage between nutrition and health, shelter and work has been appreciated. The Office of the High Commissioner for Human Rights has noted that "violating the right to food may impair the enjoyment of other human rights, such as the right to health, education or life, and vice versa." 36 Starting with Francis Mullin in the 1980s to Laxmi Mandal and Swaraj Abhiyan in this decade, courts have underscored this interrelatedness of the 'right to food', right to health, right to shelter and right to work. As discussed earlier, the Supreme Court in Francis Coralie Mullin had stated that the right to life "cannot be restricted to mere animal existence" and that it "includes the right to live with human dignity and all that goes along with it, namely, the bare necessaries of life such as adequate nutrition, clothing and shelter." 37 This observation squarely connected adequate nutrition with clothing and shelter and set the tone for a multidimensional interpretation of the right to food. Almost three decades later, the Delhi High Court emphasized on the interrelatedness of the 'right to food' and the right to reproductive health of the mother and the right to health of the infant child.

In Laxmi Mandal v. Deen Dayal Upadhyay Hospital38, the Court, while referring to directions issued in the PUCL case, observed:

There could not be a better illustration of the indivisibility of basic human rights as enshrined in the Constitution of India. Particularly in the context of a welfare State, where the central focus of these centrally sponsored schemes is the economically and

${ }^{36}$ Office of the High Commissioner for Human Rights, United Nations, The Right to Adequate Food, Fact Sheet No. 34, April 2010, http://www.ohchr.org/documents/publications/factsheet34en.pdf.

${ }^{37}$ Supra note 14.

382010 Ind law DEL 3281. 
socially disadvantaged sections of society, the above orders of the Supreme Court have to be understood as preserving, protecting and enforcing the different facets of the right to life under Article 21 of the Constitution. As already noted, these petitions focus on two inalienable survival rights that form part of the right to life. One is the right to health, which would include the right to access government (public) health facilities and receive a minimum standard of treatment and care. The other facet is the right to food which is seen as integral to the right to life and right to health. ${ }^{39}$

It is also obvious that such recognition of inter-linkages is not limited merely to a set of rhetorical claims, but has also shaped the content of the concrete relief awarded by courts. In the Kishen Pattnayak case, the Supreme Court had, while directing the constitution of the Natural Calamities Committee, broadened its mandate. The Court had stated that the Committee will not be confined just to the cases of starvation deaths, but shall also be responsible for looking after the welfare of the people of the district. This was an acknowledgement of the inextricable connection between nutrition and general welfare.

The association between right to food and other unenumerated components of right to life like shelter, livelihood and health in the field of remedies, is indicated in several interim orders of the Supreme Court in the PUCL case too. Indeed, the wide spectrum of interim orders passed in that case strongly reflect the multidimensional nature of right to food. Several of the interim orders, issued in the last 5 years, have related to shelter for homeless persons. An interim application was filed seeking directions of the Court enjoining the state governments to set up night-time shelter-homes for homeless persons residing on streets. The Supreme Court not only admitted the application but also passed directions on construction of the same in various urban

${ }^{39} I d$. 
areas. Moreover, the Commissioners and Advisors were tasked with monitoring of construction of such shelters. ${ }^{40}$

Further, many of the schemes that were turned into legal entitlements dealt as much with health and livelihood, as with nutrition. The Integrated Child Development Scheme (ICDS) and the National Maternity Benefit Scheme (NMBS) relate to maternal and neo-natal health through nutrition. Similarly, the Sampoorna Gramin Rozgar Yojana (SGRY), which was later brought within the purview of the PUCL case, pertains to livelihood and employment. The link between livelihood and right to food was also acknowledged in the recent case of Swaraj Abhiyan v. Union of India ${ }^{41}$ where the Court referred to the role of the National Rural Employment Guarantee Act and its effective implementation in addressing food insecurity in drought areas. All these decisions demonstrate Indian judiciary's appreciation of the indivisibility of right to food as a component of right to life and its inextricable connection to right to health, shelter, livelihood and other basic human rights.

A perusal of all the orders in the PUCL case and the decisions in the associated cases of Laxmi Mandal and Swaraj Abhiyan reveal that the courts have not elaborated on the systemic content of the right. None of the decisions indicate any core systemic content that the right to food possesses. Instead, the judicial discourse has focused on the benefits available and guaranteed under the various schemes and the implementation of those benefits. This model of articulating the content of the right to food, mirrors the conditional social right model, propounded by Madhav Khosla, wherein courts instead of asserting the innate content of a right, focus on measures undertaken by the state and their implementation. ${ }^{42}$ In other words, the content of the right becomes conditional upon state action. ${ }^{43}$ This implies that instead of assessing adequacy of statutory and administrative benefits against an autonomous constitutional

40PUCL v Union India, (2013) 11 SCC 505.

${ }^{41} I d$.

42Madhav Khosla, Making Social Rights Conditional: Lessons from India, 8 INT'́ J. CONST. L. 739, 742 (2010).

${ }^{43} \mathrm{Id}$. 
standard, judicial review is geared towards addressing issues in implementing the existing benefits.

That the content of the right to food is conceived as contingent upon state action is best illustrated by the observation of the Supreme Court in the Swaraj Abhiyan case where the Court stated:

No mandamus can be issued by this Court to the State Governments to implement the NFS Act beyond what is required by the terms and provisions of the statute...it is not possible for us to issue a positive direction to the State Governments to make available to any needy persons any item over and above what is mandated by the NFS Act ${ }^{44}$

That the observation in Swaraj Abhiyan is not an aberration, but in line with the established tradition of judicial dicta being concerned with issues in implementation is apparent in the PUCL case. The schemes that were turned into constitutional entitlements by the PUCL bench were all pre-existing administrative schemes that had been announced by the government.

The basis of the entitlement was not so much any autonomous systemic minimum content of the right to food as much as the existence of the schemes framed by the Government. Admittedly, the Court did modify many of the schemes, but such modifications were either driven by imperatives for implementation or guided by policy preferences. They were also not grounded on any systemic content of the right to food. The same is reflected in the decision of the Delhi High Court in the Laxmi Mandal case where compensation was awarded for non-compliance with the conditions that the National Maternity Benefit Scheme (NMBS) and the Janani Suraksha Yojana (JSY) provided. ${ }^{45}$ All these cases demonstrate that the enforceable content of the right to food in any case is being determined by the existing schemes or statutory regimes introduced by the government and not with reference to any nonderogable minima that the right connotes. As a result, adjudication of claims relating to the right to food has centered more around

${ }^{44}(2016) 7$ SCC 498.

452010 Ind law DEL 3281. 
questions of implementation of existing schemes, than around adequacy of benefits. In other words, the evolution of judicial conception of right to food vindicates the model of conditional social right proposed by Madhav Khosla.

The use of conditional social right approach to secure the right to food over a systemic content approach is not merely a matter of academic significance, but has a direct bearing on the scope of judicial review and adjudicatory remedies. For example, in the Swaraj Abhiyan case, a systemic model of right to food would have caused the Court to examine the adequacy of the benefits accorded by the National Food Security Act as against the minimum content of right to food. Instead, the conditional social right approach, as discussed earlier, led the Court to limit its analysis to the provisions and terms of the Act. Conversely, Court's emphasis on more robust implementation of existing nutrition related schemes in response to a petition asserting the right to food, begs the question as to what the response of the court would have been, if schemes like TPDS, AAY, MDMS did not already exist on paper.

Regardless of the absence of a systemic content of the right, the conditional social right approach to right to food does offer certain benefits. As Madhav Khosla argues, a conditional recognition of the right to food, as limited as it is, does perform an expressive role by changing the social meaning attached the claim of food. ${ }^{46}$ Further, by shifting the lens to the implementation of schemes and statutory regimes, courts continually remind the state of its obligations and allow the judiciary to examine state performance. ${ }^{47}$ It needs to be pointed out in this context, that the conditional social right model provides an effective response to the institutional objections to judicial enforcement of socio-economic rights. One of the most noteworthy arguments against adjudication of socio-economic rights, is that it is anti-democratic in so far as it undermines the institutional separation of powers between the judiciary, the legislative and the executive branches of the government. ${ }^{48}$ This

\footnotetext{
46 Supra note 42 .

47 Id. at 763.

${ }^{48}$ Aryeh Neier, Social and Economic Rights: A Critique, 13 (2) HUMAN RIGHTS BRIEF 1 (2006).
} 
argument is predicated on the claim that realization of such rights essentially involves policy choices and therefore are best left to political branches. 49

The conditional social right model addresses this criticism, since the courts do not frame new schemes or create new substantive rights, but only turn existing schemes into entitlements. The Court defers from the policy choices exercised by the legislative and executive branches of the government while strengthening their implementation framework under this approach. Thus, courts can escape the charge of undermining the principle of separation of powers and therefore, the conditional social rights approach can strengthen the legitimacy of judicial enforcement of right to food. However, a major weakness of this model lies in the fact that since adjudication is predicated on existing schemes and statutory regimes, absence of strong substantial benefits under applicable schemes or legal regimes may render the right to food a mere cosmetic adornment. Nonetheless, it is hoped that the conditional social right model would guard itself against its logical extreme of the right being negated by complete absence of a policy. .50

\section{Conclusion}

The past three decades have seen a gradual transformation of the right to food from a non-justiciable directive, to a fundamental right, as part of right to life guaranteed by Article 21 of the Constitution. What commenced with an expressive reference to the right to food in Francis Coralie Mullin was followed with an implied recognition of the same in the Kishen Pattnayak case. It finally culminated in an explicit recognition of the right after the 15-year long battle initiated in the PUCL case. As this paper has argued, the recognition of the right to food has not only been a matter of expressive significance but has also had a concrete impact on actual governmental policies and their implementation. This is reflected most notably in the PUCL case where several governmental food security-related schemes were given the status of enforceable legal entitlements, principles of accountability of

\footnotetext{
${ }^{49}$ Supra note 13.

50 Supra note 42.
} 
concerned officers were laid down and an institutional framework for monitoring enforcement was established.

These judiciary-driven doctrinal and institutional changes have been at the vanguard of overhaul of India's public food distribution schemes and has led to the more robust implementation of nutrition related programmes. ${ }^{51}$ They have also played the role of a catalyst in the adoption of the National Food Security Act 2013, at the central level, that provides for a statutory framework for enforcement of food security schemes and articulates the respective obligations of central and state governments, as well as those of the Panchayati Raj institutions. ${ }^{52}$ Most pertinently, the Act allows state governments continue with or formulate food or nutrition schemes that provide for higher benefits than those provided under this Act. In pursuance of this, the Tamil Nadu Government has retained its policy of universal public distribution system that is not restricted to persons only below the poverty line..$^{53}$ Similarly, the West Bengal Government has launched the Khadya Sathi Scheme that provides rice at Rs 2 per $\mathrm{kg} .{ }^{54}$ These schemes are only a few select instances of state governments initiating their own schemes on food security. Not surprisingly, the last decade has seen substantial improvement in implementation of nutrition-related schemes. According to the India Human Development Survey, leakages in PDS were reduced from 49 per cent in 2004-05 to 32 per cent in 2011-12. Reduction of leakages have been far more pronounced in the poorest states. There have also been significant gains in various nutritional indicators in the last decade with most of the poorest states being able to reduce the number of underweight children. ${ }^{55}$ These

\footnotetext{
51 Supra note 23.
}

52 Supra note 12.

53 G Anuradha, A Case for Universal PDS: Tamil Nadu's Experience, 4 (3) INT. JOURNAL OF MANAGEMENT AND DEVELOPMENT Studies 348-355 (2015).

${ }^{54}$ Expanded Bengal Food Security Scheme to Benefit 7 Crore People, Jan. 27, 2016 http://www.business-standard.com/ article/newsians/expanded-bengal-food-security-scheme-to-benefit-7-crore-people116012701243_1.html.

55 Rukmini S, Some Improvements in Child Malnutrition: data, The Hindu, Aug. 22, 2015, http:// www.thehindu.com/ data/some38 
instances illustrate that the judicial dicta on the right to food, has not merely had any symbolic value but has been able to give impetus to incremental institutional and policy changes. The other notable facet of the judicial recognition of the right to food in India has been its holistic interpretation, wherein, the linkage between nutrition and health, shelter and work has been underscored Further, as has been demonstrated by the scope of the orders issued in some of the preceding cases, such holistic approach has not been limited merely to rhetorical claims but has also shaped the content of the concrete relief awarded by courts.

This essay has also shown that the adjudicatory lens of Indian courts on the right to food have failed to articulate systemic content on what the right entails. This has resulted in a conditional approach with no autonomous content and where the corresponding obligations enjoined by the right to food are determined by the content of existing schemes and statutory regimes. While this model can provide an effective response to the claim that adjudication of socio-economic rights suffers from democratic deficit, there is a danger of weak administrative and statutory regimes denuding the right of its content. Since the contours of adjudication are shaped by existing schemes and statutory regimes, absence of adequate benefits in existing regimes may mean that judicial intervention would not carry any substantive content. As such, the conditional social right model adopted by the Indian judiciary to right to food, is a minimalist approach. Nonetheless, such a conditional model geared towards more effective implementation has the potential for transformative changes in the Indian socio-political context, characterized by a blend of broad ambitious policy pronouncements and poor administrative implementation. The incremental overhaul of the food security schemes in India, in the aftermath of judicial recognition of the right to food, stands as a testament to that.

improvements-in-child-malnutrition-data/article7566846.ece.(last accessed on April 11, 2017) 